Rev. Int. Contam. Ambie. 33 (2) 347-353, 2017

DOI: $10.20937 /$ RICA.2017.33.02.15

SHORT COMMUNICATION / COMUNICACIÓN BREVE

\title{
SYNTHESIS AND CHARACTERIZATION OF CALCIUM HYDROXIDE OBTAINED FROM AGAVE BAGASSE AND INVESTIGATION OF ITS ANTIBACTERIAL ACTIVITY
}

\author{
Leonardo CHÁVEZ GUERRERO ${ }^{1 *}$, Javier GARZA-CERVANTES ${ }^{2}$, Diana CABALLERO-HERNÁNDEZ ${ }^{3}$, \\ Rodrigo GONZÁLEZ-LÓPEZ ${ }^{4}$, Selene SEPÚLVEDA-GUZMÁN ${ }^{1}$ and Elena CANTÚ-CÁRDENAS ${ }^{2}$
}

\footnotetext{
${ }^{1}$ Facultad de Ingeniería Mecánica y Eléctrica, Universidad Autónoma de Nuevo León. Pedro de Alba, Ciudad Universitaria, San Nicolás de los Garza, Nuevo León, México, C. P. 66455

${ }^{2}$ Facultad de Ciencias Químicas, Universidad Autónoma de Nuevo León. Pedro de Alba, Ciudad Universitaria, San Nicolás de los Garza, Nuevo León, México, C. P. 66455

${ }^{3}$ Facultad de Ciencias Biológicas, Universidad Autónoma de Nuevo León. Pedro de Alba, Ciudad Universitaria, San Nicolás de los Garza, Nuevo León, México, C. P. 66455

${ }^{4}$ Facultad de Ingeniería Civil, Universidad Autónoma de Nuevo León. Pedro de Alba, Ciudad Universitaria, San Nicolás de los Garza, Nuevo León, México, C. P. 66455

*Corresponding author: guerreroleo@hotmail.com
}

(Recieved May 2016; accepted September 2016)

Key words: renewable resources, ash, bactericide, $\mathrm{Ca}(\mathrm{OH})_{2}$

\begin{abstract}
Calcium hydroxide $\left(\mathrm{Ca}(\mathrm{OH})_{2}\right)$ is recognized as an efficient bactericide and is widely applied as a root canal filler in endodontic treatment. $\mathrm{Ca}(\mathrm{OH})_{2}$ is mainly produced by hydration of calcium oxide $(\mathrm{CaO})$, a product of the thermal decomposition of calcium carbonate $\left(\mathrm{CaCO}_{3}\right)$ from sources such as limestone. In this work, calcium hydroxide particles were synthetized by the thermochemical transformation of waste biomass from the tequila industry. Agave biomass processed at $600{ }^{\circ} \mathrm{C}$ was composed mostly of calcium carbonate $\left(\mathrm{CaCO}_{3}\right)$, while calcination at $900{ }^{\circ} \mathrm{C}$ followed by hydration produced $\mathrm{Ca}(\mathrm{OH})_{2}$. The morphology and crystalline nature of the $\mathrm{Ca}(\mathrm{OH})_{2}$ particles were characterized by micro-Raman spectroscopy, scanning electron microscopy and $\mathrm{X}$-ray diffraction analysis. Bactericidal activity of synthesized calcium hydroxide was evaluated with the agar diffusion assay. Our results provide evidence that $\mathrm{Ca}(\mathrm{OH})_{2}$ obtained from agave biomass is an effective bactericidal against Escherichia coli and Enterococcus faecalis. Biomass from agave is available in Mexico and the rest of the American continent, the use of processed bagasse for medical applications could provide a venue for the useful disposition of industrial waste.
\end{abstract}

Palabras clave: recursos renovables, ceniza, bactericida, $\mathrm{Ca}(\mathrm{OH})_{2}$

\section{RESUMEN}

El hidróxido de calcio $\left(\mathrm{Ca}(\mathrm{OH})_{2}\right)$ es reconocido como un eficiente bactericida y es ampliamente utilizado como relleno de la raíz dental en tratamientos de endodoncia. $\mathrm{El} \mathrm{Ca}(\mathrm{OH})_{2}$ es producido por la hidratación del óxido de calcio $(\mathrm{CaO})$, un producto de la descomposición térmica del carbonato de calcio $\left(\mathrm{CaCO}_{3}\right)$, obtenido principalmente de piedra caliza. En el presente trabajo, se sintetizaron partículas de hidróxido de calcio 
mediante la descomposición térmica de biomasa residual de la industria tequilera. La biomasa de agave se procesó a $600^{\circ} \mathrm{C}$, la cual se compone principalmente de carbonato de calcio $\left(\mathrm{CaCO}_{3}\right)$, por lo que su calcinación a $900^{\circ} \mathrm{C}$ y posterior hidratación producen el $\mathrm{Ca}(\mathrm{OH})_{2}$. La morfología y cristalinidad de las partículas de $\mathrm{Ca}(\mathrm{OH})_{2}$ se caracterizaron mediante el uso de espectroscopía Raman, microscopio electrónico de barrido y difracción de rayos X. La actividad bactericida del hidróxido de calcio obtenido, se evaluó mediante el ensayo de difusión en agar. Los resultados proveen evidencia de la efectividad del $\mathrm{Ca}(\mathrm{OH})_{2}$, obtenido de la biomasa de agave, contra Escherichia coli y Enterococcus faecalis. La biomasa de agave se encuentra ampliamente disponible en México y el resto del continente americano, por lo que el uso de bagazo de agave procesado en aplicaciones médicas, puede proveer una alternativa en la disposición y el uso de residuos agroindustriales.

\section{INTRODUCTION}

Biomass harvest from semi-arid lands is a very promising source of supplies (Reynolds 2007), leaving cultivable lands focused on food production (Ragauskas et al. 2006). Xerophyte Agavaceae plants like Agave tequilana, are used as source of food, fibers, energy and spirit beverages such as tequila and mescal (Dalton 2005, López-Alvarez et al. 2012). The 300 known Agave species are all native from the American continent where 7500 years ago, agave fibers were used by ancient humans to make footwear (Kuttruff et al. 1998). More recently, the early 90's witnessed an increase in the popularity of tequila around the world, becoming an attractive industry, not only for Mexican but also for foreign investors. The production of alcoholic beverages from Agave typically follows five steps: cooking, milling, fermenting, distilling and ageing (Martínez-Gutiérrez et al. 2015). As result, every year the tequila industry produces high volumes of bagasse, vinasse and $\mathrm{CO}_{2}$ as byproducts of small economical value (Robles-González et al. 2012). The traditional practices for the management and disposal of bagasse waste, involve sun drying the bagasse, followed by incineration for volume reduction. This produces large quantities of ash with a narrow chemical composition, dependent of the soil mineral composition where the agave is grown, and with potential for further exploitation (Bashan et al. 2006). Addressing this situation, several applications have been developed to take benefit from the agave bagasse, such as fuel (Chávez-Guerrero and Hinojosa 2010), in papermaking (Idarraga et al. 1999), fertilizer or compost (Martínez-Gutiérrez et al. 2013, Rodríguez et al. 2013), and a renewable source of calcium compounds like $\mathrm{CaCO}_{3}$ and $\mathrm{Ca}(\mathrm{OH})_{2}$ (Chávez-Guerrero et al. 2010). In particular, $\mathrm{Ca}(\mathrm{OH})_{2}$ has a wide range of applications. For instance it has been long used as a component in cement (González-López et al. 2015) and more recently as antifungal (Gómez-Ortíz et al. 2013) and bactericidal filling of root canals in endodontic treatment (Gomes et al. 2006) as many other common applications such as food additives and a material source for the production of pulp and steel.

The aim of this work is to provide evidence of the potential use of processed agave biomass waste from the tequila industry as a bactericidal agent against pathogenic bacteria such as Escherichia coli and Enterococcus faecalis. As well as to introduce a renewable source of $\mathrm{Ca}(\mathrm{OH})_{2}$ from agave bagasse, presenting an alternative source of this compound, with the potential to diminish the ecological impact of the tequila industry.

\section{MATERIALS AND METHODS}

The agave bagasse was dried at $120^{\circ} \mathrm{C}$ for $2 \mathrm{~h}$, then placed into an alumina crucible and heated at $600^{\circ} \mathrm{C}$ for $2 \mathrm{~h}$ using a Thermolyne furnace to obtain ash, this sample was labeled ash 600 . The ash was then heated at $900{ }^{\circ} \mathrm{C}$ for $5 \mathrm{~h}$. In the next step, the ash was poured into deionized water and stirred in an ultrasonic bath for $10 \mathrm{~min}$. The samples were left to dry at $100{ }^{\circ} \mathrm{C}$ for $5 \mathrm{~h}$, the resulting sample was labeled ash 900 . All samples were obtained in triplicate. Analytical grade $\mathrm{Ca}(\mathrm{OH})_{2}$ (Sigma-Aldrich), henceforth identified as commercial, was used as standard to compare the microstructure and bactericidal activity of the analyzed samples. The morphology and composition of the samples were determined using a FEI Scanning electron microscope (SEM) model XL30 with a Schottky field emitter gun (SFEG) with an energy dispersive $\mathrm{X}$-ray microanalysis system and an acceleration voltage of $10 \mathrm{kV}$. All powders were analyzed by X-ray diffraction (XRD) in a D8 Advance Bruker powder diffractometer. The diffractogram patterns were collected from $2 \mathrm{q}=10-60^{\circ}$ using a $\mathrm{Cu} \mathrm{K} \alpha$ radiation 
$(\lambda=1.5406 \AA)$. Raman microspectrometry measurements were recorded at room temperature using a Thermo Scientific DXR Raman microscope with a $532 \mathrm{~nm}$ laser excitation. In order to test the compounds efficacy to inhibit microbial growth, an agar diffusion assay was carried on. Two bacteria were tested, Escherichia coli, ATCC 25922 (American Type Culture Collection, Rockville, MD) and Estreptoccocus faecalis, ATCC 29212. E. coli is a Gram-negative, facultative anaerobium, rod shaped bacteria, while $E$. faecalis is a non-motile, Gram-positive, facultative anaerobic microbe. Assay cultures were prepared by subculture in trypticase soy broth (Merck), culture purity was monitored by microscopy observation. Two hundred $\mu \mathrm{L}$ of culture or a ten-fold dilution were inoculated with a sterile bacterial spreader and smeared in the surface of Muller-Hinton agar plates (Bioxon). Approximately $10 \mu \mathrm{L}$ of paste, made by mixing each sample with a small volume of water, was placed in equidistant positions in the agar surface. The plates were incubated at $37^{\circ} \mathrm{C}$ for $24 \mathrm{~h}$ and later examined for inhibition halos surrounding the compounds. All tests were performed in triplicate for each microorganism.

\section{RESULTS AND DISCUSSION}

In figure 1 (a), the X-ray results show the main compounds present in the three analyzed samples. For ash 600, the resulting XRD pattern shows the reflection peaks assigned to calcium carbonate $(\boldsymbol{\Delta})$. In the case of ash 900, the XRD pattern (Fig. 1c) is associated with the hexagonal crystalline shape of calcium hydroxide.

Theoretically, it would be expected for both ash 900 and commercial samples to match the profile available for comparison in the public database (PDF 00-004-0636). However, according to the results, the samples were composed of a combination of calcium hydroxide and calcium carbonate (Fig. 1e). It could be argued that $\mathrm{CO}_{2}$ was adsorbed by the samples during air exposure, resulting in a partial carbonation of the sample. In support of this explanation, a peak observed at $28.5^{\circ} \mathrm{C}$ (unexpected for a calcium hydroxide sample) can be attributed to the repeated exposure of the reactive grade powder to the $\mathrm{CO}_{2}$ in the environment, once the container has been opened, producing a partial carbonation of the sample. Equation 1 represents the reaction occurring to $\mathrm{CaCO}_{3}$ (ash) during the heating process. In this process, $56 \%$ $(\mathrm{w} / \mathrm{w})$ of the ashes remain as calcium oxide, then by burning $1000 \mathrm{~kg}$ of ash approximately $560 \mathrm{~kg}$ of $\mathrm{CaO}$ could be produced, leaving the total net $\mathrm{CO}_{2}$ emissions unaffected (Chávez-Guerrero et al. 2010).
$\mathrm{CaCO}_{3} \stackrel{900^{\circ} \mathrm{C}}{\longrightarrow} \mathrm{CaO}+\mathrm{CO}_{2}$

Equation 2 represents the intermediate exothermic reaction to obtain calcium hydroxide, where lime is mixed with water to obtain $\mathrm{Ca}(\mathrm{OH})_{2}$. The treatment of $560 \mathrm{~kg}$ of $\mathrm{CaO}$ with water would produce 740 $\mathrm{kg}$ of calcium hydroxide. Equation 3 represents the carbonation of calcium hydroxide, which occurs spontaneously in the presence of $\mathrm{CO}_{2}$. Equation 3 thus, represents the behavior exhibited by the ash 900 and commercial sample, which exposure to environmental $\mathrm{CO}_{2}$ produced calcium carbonate, this was also suggested by the XRD results, shown in figure 1 .

$\mathrm{CaO}+\mathrm{H}_{2} \mathrm{O} \rightarrow \mathrm{Ca}(\mathrm{OH})_{2}$

$\mathrm{Ca}(\mathrm{OH})_{2}+\mathrm{CO}_{2} \rightarrow \mathrm{CaCO}_{3}+\mathrm{H}_{2} \mathrm{O}$

In figure 1b the original structure of the Agave fibers can still be discerned with small semicircular particles, while in ash 900 hexagonal crystals, characteristic of $\mathrm{Ca}(\mathrm{OH})_{2}$ can be observed (Fig. 1d). In figure 1f the commercial sample shows irregular particle shapes, this might be attributed to the use of grinded limestone during the production process of $\mathrm{Ca}(\mathrm{OH})_{2}$. Even if unexpected, the presence of $\mathrm{CaCO}_{3}$ in the bagasse, can be explained by plant physiology, plants are able to break and solubilize rock by excreting acidic compounds in root exudates (Bashan et al. 2006). This mechanism is used to obtain minerals from poor soils, providing an alternative source of nutrients. As such, this natural occurring mechanism could be exploited for the extraction of several compounds of economic interest, once the biomass has been used in the tequila manufacturing process.

Figure 2 shows the Raman spectra of ash 600 displaying the four characteristic peaks of $\mathrm{CaCO}_{3}$, while for the spectrum of ash 900, besides the expected peaks (Table I), displays an additional peak at $358 \mathrm{~cm}^{-1}$, suggesting the presence of hydrated lime (Tlili et al. 2002, Schotsmans et al. 2014). The Raman spectra of the commercial sample shows identical peaks to those obtained for $\mathrm{Ca}(\mathrm{OH})_{2}$. As it can be observed in the XRD patterns, both ash 900 and commercial samples contain a mixture of $\mathrm{Ca}(\mathrm{OH})_{2}$ and $\mathrm{CaCO}_{3}$, even though the peaks in the Raman spectra are similar in the samples of $\mathrm{CaCO}_{3}$ and $\mathrm{Ca}(\mathrm{OH})_{2}$. The explanation for this peak at 358 $\mathrm{cm}^{-1}$ is the presence of hydrated lime. Calculating the relative intensity (I/Io) of the peak associated to the hydrated lime $\left(358 \mathrm{~cm}^{-1}\right)$, it is possible to study the carbonation of $\mathrm{Ca}(\mathrm{OH})_{2}$ samples as shown in table $\mathbf{I}$. 
(a)

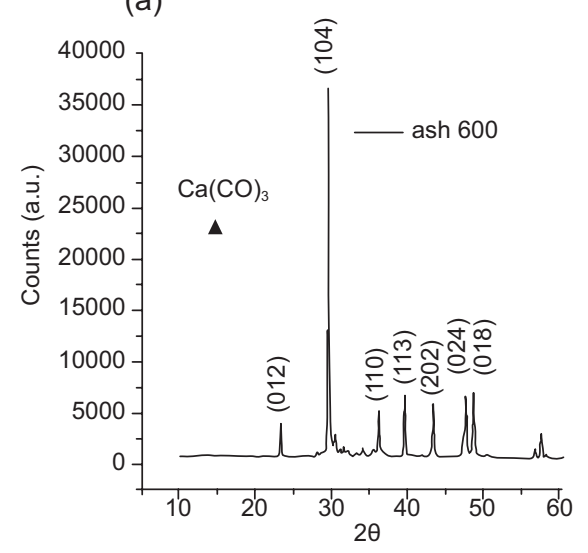

(c)

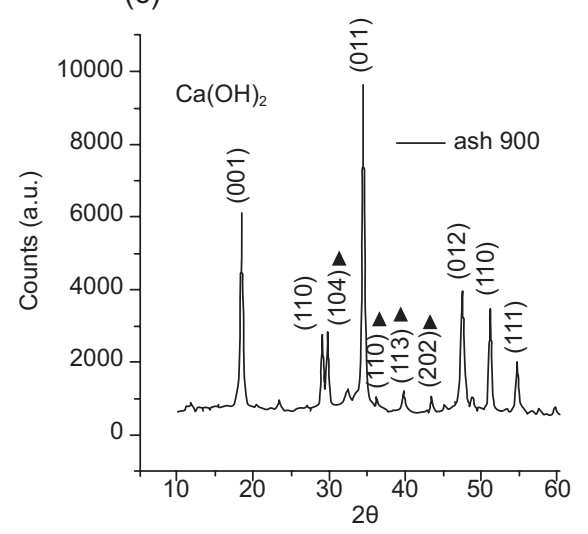

(e)

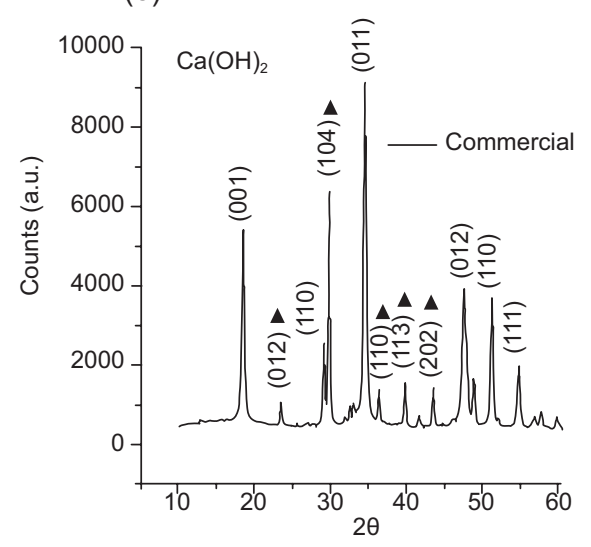

(b)

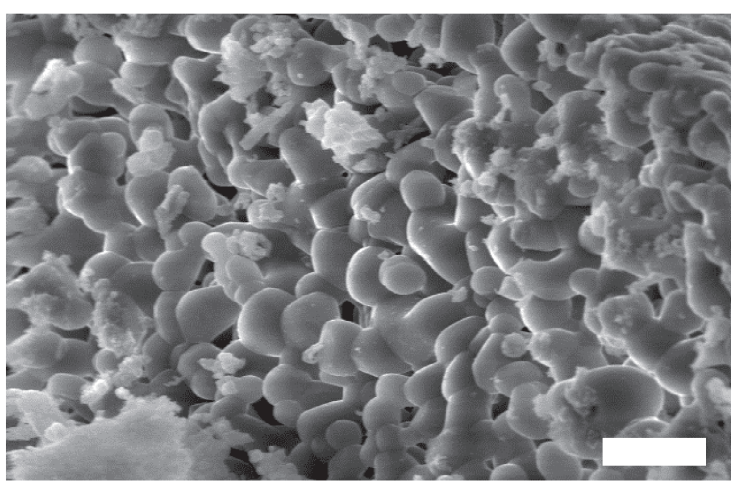

(d)

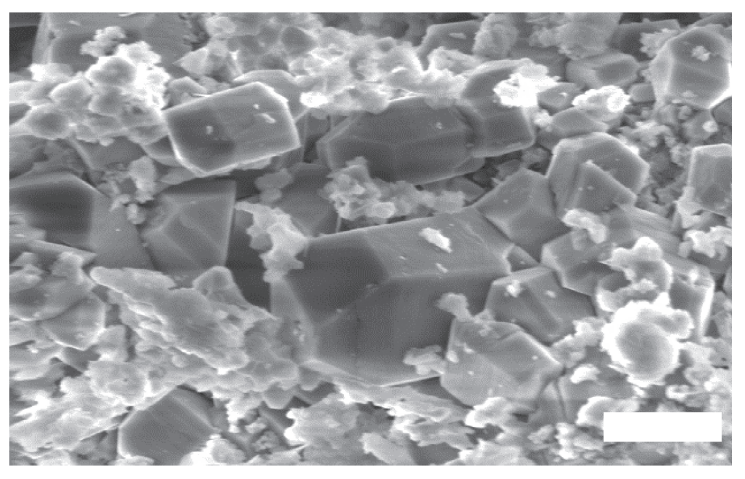

(f)

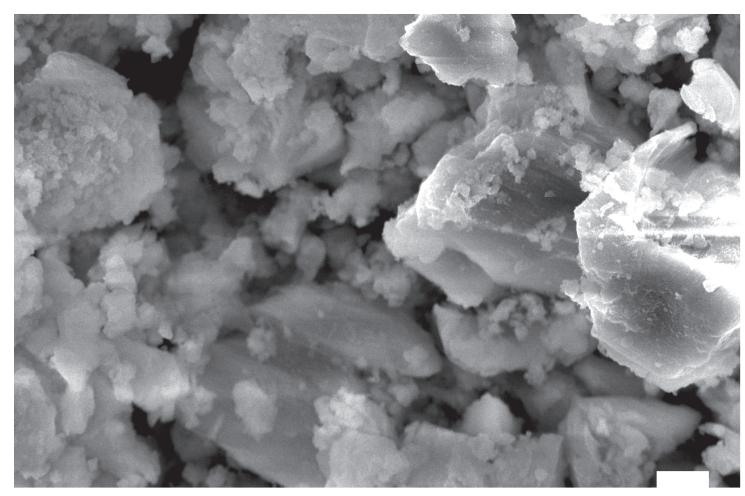

Fig. 1. Diffractogram patterns of the samples and scanning electron microscope images showing the morphology of (a-b) ash 600, (c-d) ash 900 and (e-f) commercial sample. Scale bar $2 \mu \mathrm{m}$. a. u. = arbitrary units 


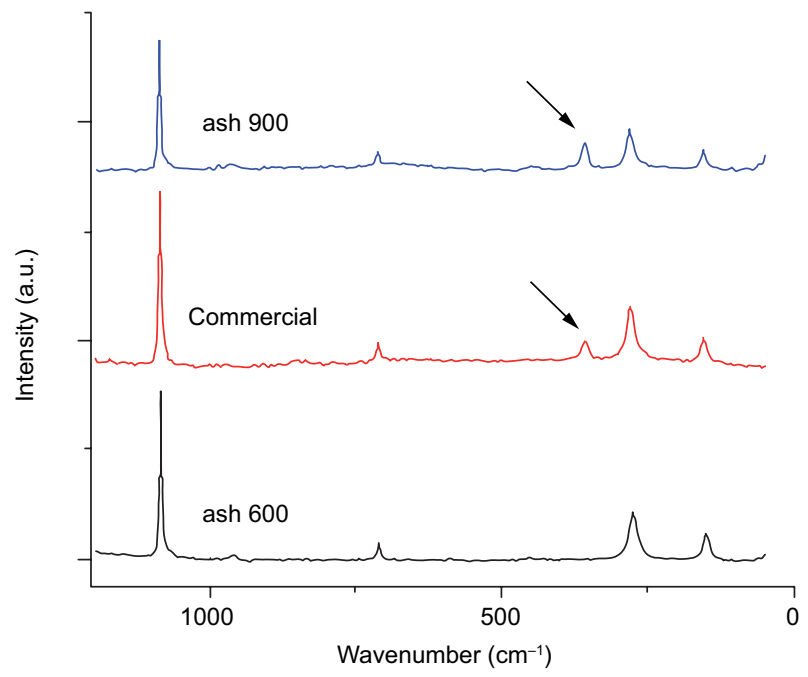

Fig. 2. Raman spectra of the three samples studied. The arrow indicates the peak at $358 \mathrm{~cm}^{-1}$. a.u. $=$ arbitrary units

Table I shows the relative intensity (I/Io) of the analysis, where both commercial sample and ash 900 exhibit the $358 \mathrm{~cm}^{-1}$ peak. It can be seen that the relative intensity is $12.7 \%(\mathrm{I} / \mathrm{Io}=(398.7 / 3139.1) \times 100)$ for the commercial sample and $20.7 \%(\mathrm{I} / \mathrm{Io}=(339.6 / 2371.0) \times 100)$ for ash 900 , indicating a lower carbonation of the sample obtained from the agave bagasse (Schotsmans et al. 2014), something that can be corroborated by the XRD results and SEM images shown in figure 1. These differences in the carbonation degree between ash 900 and commercial sample might be attributed to a longer exposure of $\mathrm{Ca}(\mathrm{OH})_{2}$ to the environment, unlike ash 900 , synthetized from $\mathrm{CaO}$ just a few hours before all the tests were performed. These observations suggest that $\mathrm{Ca}(\mathrm{OH})_{2}$ must be synthesized just before its application as bactericidal agent for maximum efficacy, thus avoiding the creation of $\mathrm{CaCO}_{3}$, which lacks antibacterial properties.
For the agar diffusion assay, after a $24 \mathrm{~h}$ incubation, E. coli and E. faecalis were observed covering the agar plate surface, displaying inhibition halos surrounding both samples of $\mathrm{Ca}(\mathrm{OH})_{2}$ ash 900 and commercial sample, while no effect was observed for calcium carbonate (ash 600), as it can be seen in figure 3a-b. In figure 3b, an amplification of the inhibition halo is presented. For E. faecalis, the width of the halo is about the same for commercial sample $(1.7 \mathrm{~mm})$ and ash $900(2.1 \mathrm{~mm})$, respectively. The ash 600 sample did not show an effect on bacterial growth, excluding the possibility of an inherent bactericidal activity of unprocessed ash.

In the case of $E$. coli, the inhibition halo width is very similar for ash $900(1.9 \mathrm{~mm})$ and commercial sample $(2.1 \mathrm{~mm})$. Nevertheless, halo size is not the main factor to consider for most of the potential applications, since the putative mechanisms for $\mathrm{Ca}(\mathrm{OH})_{2}$ bactericidal activity are contact-mediated.

\section{CONCLUSIONS}

The successful synthesis of calcium hydroxide using bagasse produced by the tequila industry was demonstrated by the XRD and the Raman spectroscopy analysis. According to the results, it can be concluded that $\mathrm{Ca}(\mathrm{OH})_{2}$ obtained by the thermochemical transformation of Agave bagasse harvested from semi-arid lands, exhibits antimicrobial activity against $E$. coli and E. faecalis, two pathogenic microorganisms of relevance. The synthesis of $\mathrm{Ca}(\mathrm{OH})_{2}$ from Agave bagasse and its antimicrobial activity provide evidence to support the continuous use of industrial byproducts.

Most importantly, biomass from Agave is abundantly available in Mexico, and the use of processed bagasse for medical applications could provide a venue

TABLE I. VIBRATIONAL WAVENUMBER $\left(\mathrm{cm}^{-1}\right)$, INTENSITIES IN ARBITRARY UNITS AND RELATIVE INTENSITY (\%), WITH DISPERSIVE RAMAN SPECTROSCOPY AT $532 \mathrm{~nm}$ EXCITATION

\begin{tabular}{|c|c|c|c|c|c|c|c|c|}
\hline \multicolumn{3}{|c|}{ ash 600} & \multicolumn{3}{|c|}{ Commercial } & \multicolumn{3}{|c|}{ ash 900} \\
\hline W & I & I/Io & W & I & I/Io & W & I & I/Io \\
\hline 150.8 & 472.3 & 15.2 & 154.7 & 430.9 & 13.7 & 155.7 & 339.6 & 14.3 \\
\hline 277.2 & 839.4 & 27.1 & 281.0 & 1032.3 & 32.8 & 282.0 & 738.4 & 31.1 \\
\hline 1. & & - & 357.2 & 398.7 & 12.7 & 358.2 & 492.6 & 20.7 \\
\hline 711.1 & 306.1 & 9.8 & 712.0 & 363.8 & 11.5 & 713.0 & 334.1 & 14.0 \\
\hline 1084.2 & 3097.0 & 100.0 & 1085.2 & 3139.1 & 100.0 & 1087.1 & 2371.0 & 100.0 \\
\hline
\end{tabular}

$\mathrm{W}=$ wavenumber $\mathrm{I} / \mathrm{Io}=$ relative intensity $\mathrm{I}=$ intensity 
a)
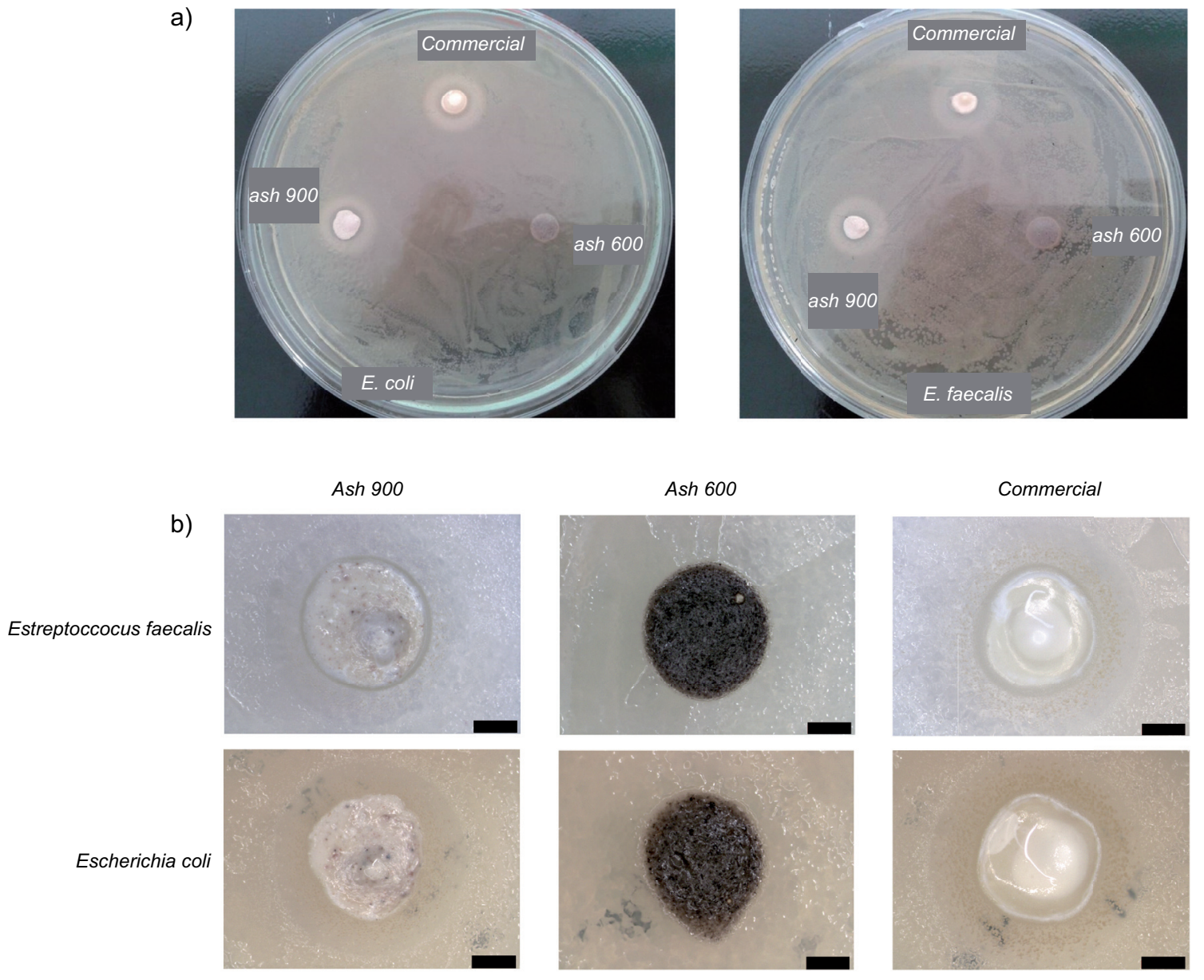

Fig. 3. a) Agar diffusion assay showing inhibition halos surrounding ash 900 and commercial sample, b) Halos seen under the optical microscope at $8 x$. Scale bar $2 \mathrm{~mm}$

for the useful disposition of industrial waste with an added value to the environment. Future work will focus on determining the extent of the bactericidal properties of $\mathrm{Ca}(\mathrm{OH})_{2}$ obtained from Agave bagasse. These properties will be tested against commercial $\mathrm{Ca}(\mathrm{OH})_{2}$, over longer periods of time and a battery of several pathogenic bacteria using solid and liquid media.

\section{ACKNOWLEDGMENTS}

To Programa de Apoyo a la Investigación Científica y Tecnológica, project IT465-15. To Centro de Innovación, Investigación y Desarrollo en Ingeniería y Tecnología and Facultad de Ingeniería Mecánica y Eléctrica. To Universidad Autónoma de Nuevo León.

\section{REFERENCES}

Bashan Y., Vierheilig H., Salazar B. and de-Bashan L. (2006). Primary colonization and breakdown of igneous rocks by endemic, succulent elephant trees (Pachycormus discolor) of the deserts in Baja California, Mexico. Naturwissenschaften 93 (7), 344-347. DOI: $10.1007 / \mathrm{s} 00114-006-0111-4$

Chávez-Guerrero L. and Hinojosa M. (2010). Bagasse from the mezcal industry as an alternative renewable energy produced in arid lands. Fuel 89 (12), 4049-4052. DOI: 10.1016/j.fuel.2010.07.026

Chávez-Guerrero L., Flores J. and Kharissov B. (2010). Recycling of ash from mezcal industry: A renewable source of lime. Chemosphere 81 (5), 633-638. DOI: $10.1016 / j$.chemosphere.2010.08.042 
Dalton R. (2005). Alcohol and science: Saving the agave. Nature 438, 1070-1071. DOI: 10.1038/4381070a

Gomes B.P., Vianna M.E., Sena N.T., Zaia A.A., Ferraz C.C. and de Souza Filho F.J. (2006). In vitro evaluation of the antimicrobial activity of calcium hydroxide combined with chlorhexidine gel used as intracanal medicament. Oral Surg. Oral Med. Oral Pathol. Oral Radio Endod. 102 (4), 544-550.

DOI: $10.1016 /$ j.tripleo.2006.04.010

Gómez-Ortíz N., De la Rosa-García S., González-Gómez W., Soria-Castro M., Quintana P., Oskam G. and Ortega-Morales B. (2013). Antifungal coatings based on $\mathrm{Ca}(\mathrm{OH})_{2}$ mixed with $\mathrm{ZnO} / \mathrm{TiO}_{2}$ nanomaterials for protection of limestone monuments. Appl. Mater. Interfaces 5 (5), 1556-1565.

DOI: $10.1021 / \mathrm{am} 302783 \mathrm{~h}$

González-López J., Ramos-Lara J., Zaldivar-Cadena A., Chávez-Guerrero L., Magallanes-Rivera R. and Burciaga-Díaz O. (2015). Small addition effect of agave biomass ashes in cement mortars. Fuel Process. Technol. 133, 35-42.

DOI: 10.1016/j.fuproc.2014.12.041

Idarraga G., Ramos J., Zuñiga V., Sahin T. and Young R. (1999). Pulp and paper from blue agave waste from tequila production. J. Agric. Food Chem. 47 (10), 4450-4455.

DOI: $10.1021 / \mathrm{j} 990045 \mathrm{n}$

Kuttruff J. T., DeHart S.G. and O’Brien M.J. (1998). 7500 Years of prehistoric footwear from Arnold research cave, Missouri. Science 281 (5373), 72-75.

DOI: $10.1126 /$ science.281.5373.72

López-Alvarez A., Díaz-Pérez A.L., Sosa-Aguirre C., Macías-Rodríguez L. and Campos-García J. (2012). Ethanol yield and volatile compound content in fermentation of agave must by Kluyveromyces marxianus UMPe-1 comparing with Saccharomyces cerevisiae baker's yeast used in tequila production. J. Biosc. Bioeng. 113 (5), 614-618.

DOI: $10.1016 /$ j.jbiosc.2011.12.015

Martínez Gutiérrez G.A., Íñiguez Covarrubias G., OrtizHernández Y.D., López-Cruz J.Y. and Bautista Cruz A. (2013). Tiempos de apilado del bagazo del maguey mezcalero y su efecto en las propiedades del compost para sustrato de tomate. Rev. Int. Contam. Ambie. 29 (3), 209-2016.

Martínez-Gutiérrez G.A., Ortiz-Hernández Y.D., AquinoBolaños T., Bautista-Cruz A. and López-Cruz J.Y. (2015). Properties of Agave angustifolia Haw. bagasse before and after its composting. Com. Sci. 6 (4), 418. DOI: $10.14295 /$ cs.v6i4.800

Ragauskas A.J., Williams C.K., Davison B.H., Britovsek G, Cairney J., Eckert C.A., Frederick Jr. W.J., Hallett J.P., Leak D.J., Liotta C.L., Mielenz J.R., Murphy R., Templer R. and Tschaplinski T. (2006). The path forward for biofuels and biomaterials. Science 311 (5760), 484-489.

DOI: $10.1126 /$ science. 1114736

Reynolds J.F., Smith D.M.S., Lambin E.F., Turner B.L., Mortimore M., Batterbury S.P.J., Dowlatabadi H., Fernández R.J., Herrick J.E., Huber-Sannwald E., Jiang H., Leemans R., Lynam T., Maestre F.T., Ayarza M. and Walker B. (2007). Global desertification: Building a science for dryland development. Science 316 (5826), 847-51. DOI: $10.1126 /$ science. 1131634

Robles-González V., Galíndez-Mayer J., RinderknechtSeijas N. and Poggi-Varaldo H. (2012). Treatment of mezcal vinasses: A review. J. Biotechnol. 157 (4), 524-546. DOI: 10.1016/j.jbiotec.2011.09.006

Rodríguez R., Jiménez J.F., Del Real J.I., Salcedo E., Zamora J.F. and Íñiguez Covarrubias G. (2013). Utilización de subproductos de la industria tequilera. Parte 11. Compostaje de bagazo de agave crudo y biosólidos provenientes de una planta de tratamiento de vinazas tequileras. Rev. Int. Contam. Ambie. 29 (4), 303-313.

Schotsmans E., Wilson A., Brettell R., Munshi T. and Edwards H. (2014). Raman spectroscopy as a nondestructive screening technique for studying white substances from archaeological and forensic burial contexts. J. Raman Spectrosc. 45 (11-12), 1301-1308. DOI: $10.1002 /$ jrs. 4526

Tlili M.M., Amor M.B., Gabrielli C., Joiret S., Maurin G. and Rousseau P. (2002). Characterization of $\mathrm{CaCO}_{3}$ hydrates by micro-Raman spectroscopy. J. Raman Spectrosc. 33 (1), 10-16. DOI: 10.1002/jrs.806 